\title{
The Wellington Cemetery Desecrations of 2004: Their Impact on Local Jews
}

\author{
HAL LEVINE AND MICHELLE GEZENTSVEY \\ Victoria University of Wellington
}

While walking to work through Wellington's Botanical Gardens on 16 July 2004, Ann Beaglehole noticed that headstones in the Jewish section of the historic Bolton Street cemetery were smashed and a swastika carved into the ground. She contacted David Zwartz, head of the New Zealand Jewish Council and Honorary Consul of Israel. After examining the scene, Mr Zwartz stated that the vandalism was connected to the remarks made the day before by the Prime Minister, Helen Clark, who strongly condemned Israel after the sentencing of two Mossad agents for attempting illegally to obtain New Zealand passports.

New Zealand Jews, a small and quiet minority, had an unaccustomedly high profile in the news during the weeks to follow. Not only were they linked to an action by Israel that the New Zealand government characterized as a violation of the nation's sovereignty, but at this time the Jewish Council was also arguing that Holocaust denier David Irving should not be allowed to enter the country. A few weeks after the Bolton Street incident, a more dramatic attack occurred at the cemetery in Makara. These events, and responses to and reflections on what happened, provide an opportunity to see how local Jews perceive their place in New Zealand society.

This paper presents interpretations of the desecrations by people who were personally involved with the events surrounding them. As members of the Wellington Jewish community, both authors took part in the activities mentioned below and were able to ascertain who organized and guided the community's response. We interviewed 22 'high profile' individuals to obtain a detailed understanding of the impact of the desecrations. Our interviews were semi-structured conversations that took about one hour. They were held in respondents' homes and workplaces or Hal Levine's office. We encouraged informants to tell us who they felt were responsible for the desecrations, what they did in reply to them, and what they thought of the overall Jewish and gentile responses. Our aim here is to present to readers a 
synthetic account of our informants' understandings of the attacks and their meaning that simultaneously provides a published record of what happened as a result of the 2004 Jewish cemetery desecrations in Wellington.

\section{A Brief Background}

The Israeli intelligence agency, Mossad, has a history of using the passports of neutral countries to help its agents to carry out operations. Two agents were arrested in Auckland on 23 March 2004 after attempting to obtain passports using the names of disabled New Zealanders. People unable to travel are unlikely to have previously applied for passports, so they tend to be targeted for this type of activity. The agents in this particular case acquired a list of such names from a member of the Auckland Jewish community who was a healthcare worker.

The Israeli government neither explained nor apologized for their actions and the New Zealand administration made a strong public protest. After the men were sentenced to a short term in prison on 15 July, the Prime Minister accused Israel of breaching New Zealand's sovereignty and imposed diplomatic sanctions on Israel.

Overnight, the Jewish section of Bolton Street cemetery was desecrated. In response to the vandalism, Rabbi Anthony Lipman, Dave Moscowitz, and other leaders of Wellington's Orthodox and Progressive Jewish congregations organized a rededication service that was held on Sunday 25 July. The service, attended by Jews and gentiles, demonstrated support for the Jewish community and its historic place in Wellington.

The attack at Makara Cemetery happened on 6 August. More than 90 gravestones in the Orthodox Jewish section of the cemetery were turned over and the prayer house on the site was burnt down. This attack, a more comprehensive and serious assault on the Wellington Jewish community, led to a flurry of activity.

The city of Wellington acted promptly to restore the damaged graves. The Australasian Union of Jewish Students (AUJS) organized a petition at Victoria University condemning all forms of anti-Semitism and discrimination. The university's Students' Association passed a statement condemning anti-Semitism on Wednesday 11 August. The AUJS petition with over 1000 signatures was presented to Minister of Ethnic Affairs, Chris Carter, at Parliament. A Youth against Hatred Rally was held in Auckland's Aotea Square on 12 August. The Wellington Hebrew Congregation held a community meeting on 12 August and organized a rededication service at Makara for Sunday 15 August. This more specifically Jewish event attracted one of the largest turnouts the Wellington community had seen. 
The New Zealand Parliament unanimously condemned anti-Semitism on 10 August, and Speaker of the House Jonathan Hunt sent the statement to Israel's parliament, the Knesset. The government banned Irving from visiting New Zealand on 14 August, after he offered a reward for information about the vandalism which was accompanied by insinuations that it was a Jewish and/or Israeli act. A Multicultural Aotearoa meeting in Newtown on 14 August was held to protest an upcoming National Front march. Since the National Front was suspected of having carried out the desecrations, Jews expected that this forum would support the Jewish community. However, it gave voice to anti-Zionist and anti-Israel opinion. The tone inside the meeting, and the National Front members picketing outside it, made Jewish attendees uncomfortable. A more constructive initiative, the Diversity Forum at Parliament, was organized by Anthony Haas with James and Helen McNeish and Race Relations Conciliator Joris De Bres. This led to the formation of the Diversity Action Programme, a continuing project to promote multicultural tolerance and understanding in New Zealand.

The Israeli spies, debate over Irving and freedom of expression, the desecrations and activities of the National Front presented a set of problems for New Zealand Jews that led them to question whether they needed to reconsider the ways in which they manage their relationships with the rest of New Zealand.

\section{Jews in New Zealand}

Writing about New Zealand Jews in the 1990s, Levine noted ${ }^{1}$ an interesting parallel between local Jewry and the situation of Greek Jews. Lewkowicz ${ }^{2}$ says that the Jewish residents of Thessaloniki privatize their Jewishness, not from fear of anti-Semitism, but because Greek nationalism, phrased as it is in terms of Greek Orthodox Christianity, leaves no room for the idea of a native Jewish identity. Levine suggested that New Zealand Jews, who similarly privatize their Jewishness and do not fear anti-Semitism, also find themselves short of space to construct a New Zealand Jewish identity:

This may sound odd because New Zealand officially embraces cultural pluralism. However, the ideology of cultural pluralism here stresses biculturalism. The aim of biculturalism is to renegotiate the relationship between Maori and the state. Although individuals of many other backgrounds inhabit this land, and enjoy a full range of freedoms and human rights, their cultural concerns never enter the public arena. Jews in New Zealand are pakeha like everyone else with white skin . . . it's Jewish with a small $\mathrm{J}$.

The cemetery desecrations show some of the limitations of inhabiting such a small conceptual space. These events were linked, at least in the minds 
of prominent Jewish and gentile commentators, to the passport swindle perpetrated by Mossad. Although their actions in Auckland were preceded by other efforts to obtain foreign passports, Ze'ev Schiff noted in Ha'aretz that 'unlike Mossad's previous attempts to get forged foreign passports, the New Zealand case was worse because it involved a local Jew, causing damage to Israel and to the reputation of New Zealand Jews. ${ }^{3}$ Phil Goff, Acting Prime Minister at the time, expressed annoyance that the Auckland Jewish Council did not condemn the role that one of its former members played in helping the Israelis:

I would have expected people to have been quite straightforward - to say we don't condone anyone coming to this country and committing acts that are against the law, particularly those that undermine our sovereignty and the integrity of our travel documents. I would have expected that comment would have been made quite clearly. Perhaps it hasn't been as clear as it should have been. For those who are claiming this has nothing to do with the Israeli intelligence agencies - [the agents] are just common criminals who happen to be Israelis - then I'm amazed that they have any criticism of the treatment they have received. ${ }^{4}$

Goff was asking local Jews to declare that their primary allegiance is to New Zealand, in a way that clearly calls their commitment to the country into question. They were being challenged to respond, especially after the desecrations that seemed closely linked to the hard line the government took towards the Israelis. Continuing to privatize Jewishness became problematical in these circumstances, as is the notion that New Zealand is devoid of antiSemitism or that it is a matter of no real consequence. The events around the spies and cemeteries clearly undermined, at least in the short term, a basic strategy and allied belief about the nature of Kiwi Jewishness. The public and official responses provided an opportunity for Jews to gauge concretely how their concerns are perceived and acted on in New Zealand. We asked our informants to reflect upon these issues.

Some thought that the desecrations demonstrated the folly of making the Jewish presence felt in New Zealand. Going public plays into the hands of the perpetrators:

... all that would do would be to make the person who did it proud, and give them publicity. Three P's: avoid perpetrator pride. deny perpetrator publicity. limit provocation for subsequent attacks . . . I don't think you want to single yourself out. Probably what I was trying to say before is that it's important that we portray ourselves as New Zealanders, just a particular sect of New Zealanders. 
Another informant's comments, about her experiences in the youth group B'nei Akiva, suggested that this will not work:

I remember doing a programme with the seniors about what it's like to be the only Jew in your high school . . . and these kids, the most secular perhaps non-identifying . . . all said that other people had come up to me and talked to me and other people had made up a nickname for me that had the word Jew in it . . . O Or sometimes we'd be studying Judaism and all of a sudden it would come up ... And all these things came out when we were talking about Bolton Street, about how you think that you can push away your identity as much as you want but even if you don't bring it up, other people will bring it up for you.

It is interesting to note that hazing (or institutionalized bullying) at school formed part of our interview with the informant who felt that keeping quiet is best. He recounted a surprisingly intense experience of anti-Semitic bullying at his secondary school but found that it stopped when he ceased reacting to the taunts and physical aggression directed at him. Another young informant found that the desecrations led some local university students who never attended AUJS functions to affiliate with the group for the first time. However, coming together only in reaction to negative events is not the kind of solidarity that she thought would ultimately benefit New Zealand Jewry: 'I think if we have a profile we need to strive to make it as proactive as we can as opposed to reactive'.

Another young Jewish leader said that the turnout for the events surrounding the desecrations was not an indication of a positive sense of Jewishness. He cited an article with which he strongly agreed, written by the Wellington Hebrew Congregation President Gary Stone in the November 2004 edition of the Centre News:

He [Gary] starts off talking about the solidarity that took place at Makara cemetery and the numbers, the droves of people that came to commemorate, to mourn, to stand together, and then he contrasted that to one or two events that took place around October time, which was one to two months after. I'll quote here from Gary Stone's article: 'I think the fact that we came in droves to rededicate headstones way out at Makara but fail to congregate at our own community epicentre is pathetic. ... Meaning no disrespect to the dead, we showed up and wept at the Cemetery and condemned the shocking abuse of their memory and disturbance of their eternal rest. But how much more of an abuse is it to then fail to show up at the place they treasured in their lifetime to disavow their principles and proceed to ignore what they were - Jews. I think the fact that we converged to focus on the dead but failed to celebrate the living, the fact that we were consumed by grief and misery 
and failed to take advantage of the anti-dote, the festival of Sukkot called by the Torah the Season of Rejoicing, supposedly the happiest time of the year, is simply tragic.' I myself am certainly not the first and the last, as a Jewish New Zealander who's also modern Orthodox in practice, I feel that for someone like myself there's not much of a future as a Jew living a Jewish life in New Zealand. It's a community where it's hard to be a Jew. It's hard to practise Orthodoxy, for example, Kashrut and Shabbath observance ... If I ended up living here, would I want to live a life so restricted and so depressing just to keep this community strong? Is this enough?

These comments provide an interesting illustration of the aforementioned restricted space for Kiwi Jews. The young man who made them migrated to Israel a short time after the interview. His aliya (Hebrew 'ascending', used in reference to migrating to Israel) provides a concrete illustration of how the lack of significant dimensions to Jewish life in New Zealand outside of religion puts firm limits on the kinds of Jewish identity that can flourish here. This informant found the community lacking; 'deteriorating' is a word used often in this interview because religious observance is declining. Part of this decline is due to the fact that people like him leave to live in more observant environments. Secular Jewish symbols - Israel, the holocaust and anti-Semitism - are important to New Zealand Jews but do not form part of a coherent national Jewish identity as they do in the USA, where civil Judaism reinforces the American-ness of American Jews. ${ }^{5}$ Indeed, our informants did not even raise the possibility of something along these lines developing. Supporting Israel, during the passport scandal and more recently in regard to the fighting with Hizbollah, puts local Jews off-side with mainstream New Zealand opinion.

This lack of fit between Jewish ideology and New Zealand nationalism may be due to a lack of creativity, stifled more by the low profile of the community than by an absence of possible resources to build a Kiwi Jewish identity. The vandalism at Bolton Street was perceived, by the Mayor of Wellington and other gentile New Zealanders, as an attack on the city's heritage. Although New Zealanders may see Israel as overly aggressive and not be particularly sensitive to Jewish concerns in general, the government does stress the value of cultural diversity and tolerance. Jews do, in fact, have room to celebrate purely Jewish events publicly, and have done so in the recent past. One informant remembered that a former Wellington Rabbi 'had initiated the lighting of a public Hannukiah' (this was in Civic Square Wellington, during the eight days of Hannukah, along with giving jelly donuts to passers-by): 'That's beautiful to me. That's amazing. That's a very 
public way of representing a really beautiful festival, and it doesn't come with the baggage of politics. Stuff like that I think is really amazing.'

After the Makara desecrations, two Wellington women stepped forward to make forceful statements about the events:

We were one of the first families probably to go to the cemetery [Makara] ... It was really an awful experience because the press were there. They were taking photos of her reaction which we didn't realize when it was being taken. Then, someone came up from the Dominion Post and said would she mind being interviewed. We had a very quick discussion then and there about whether we would or not, and I had a very strong view that you don't shy away from who you are . . . My family is very well known in Wellington and my father's grave had been desecrated. He was very much, 'You should always stand up for who you are' . . So, my mother and I came to a very quick decision that we were going to be public about it.

And behind all this I knew that there were some people in the community who were scared . . . and they didn't want to be identified and I detest that. I certainly came up against people who said, 'Look, you're making yourself a target, you've got a business you've got a family', and I just, I don't believe shying away protects you. It didn't protect us from the Nazis; it wouldn't protect us here. If someone wants to find out that I'm Jewish, they can find out very easily. I'm not shying away. And I won't let my children shy away either. [My son] was asked at school whether he would address the school assembly. I was immensely proud of him. He spoke from the heart and it was a very proud moment for me to watch him do that. It's those moments when you teach your children to stand up for their beliefs and either you mean that or you don't . . I don't believe that in taking that role I put myself or my family in any greater danger than we are already just by the fact that we are Jewish. I assess that danger as fairly low anyway.

The other woman said:

We were fortunate that our children are at a secondary school where the principal took a very strong stand against what happened and contacted me a day after it happened and spoke about it at the College mothers' group. He said, 'We're just not a country that's going to tolerate that'. And he said, 'I've spoken to S. and others'. He identified me in front of this group of college mothers. I thought, 'What am I going to do?' This man has gone quite far out on a limb to defend the Jewish people and I can't let that go unthanked. So, I stood up and thanked him for his public denouncement. I said, 'I feel I can talk among friends because although I don't know all of you', I knew ten well out of the 
group of 30 or 40 . It was for me, the whole intolerance, whether it was against Indians, or Somalis or Jews, it was very shocking. I think a lot of Jewish people felt that they were offended not only for themselves but offended for New Zealanders. And I think a lot of New Zealanders who are not one racial group or another felt that way. So, I said that and I felt really exposed. Like I had taken my clothes off in front of them all, or probably worse. But, after that people came up and smiled at me. I'm never sure if they are smiling because now they know who I am or 'there's that Jewish girl'. I was a bit anxious if it was the wrong thing to say or the wrong forum but I did what felt right at the time. That was a pivotal event and it was pivotal for my behaviour, how I behave because of it. I was asked to be interviewed by journalists as one person who had relatives at both cemeteries. I talked to my wider family about it, [and] they didn't want us identified publicly. Because of the implications. That wasn't how we were brought up. Though I have changed, we haven't all changed.

Coming out as Jews seemed to work well for these informants. They derived personal satisfaction from and were proud of their actions. They gave the impression that there was a tipping point of sorts. It was an uncomfortable choicē that could have worked out badly but ended well. And that was how things worked out for the Jewish community as a whole, at least from the perspective of our interviews. The Jewish reaction to the desecrations and the acceptance of diversity by the government and mainstream New Zealand population turned what could have been an amplification of Goff's insistence that local Jews make a choice between loyalty to New Zealand and Israel into an understanding that Jews in New Zealand have a right to be here on their own reasonable terms. However, negotiating this understanding, an accomplishment of politically-savvy local Jews and well-meaning influential gentiles, shows how small the Jewish space in New Zealand really is.

New Zealand's race relations conciliator, Joris de Bres, took an active part in promoting a harmonious approach to the desecrations:

Whenever something like this comes to my attention I try to think, 'What's the best way I can add value here?' It was going to be condemned by a lot of people. There is no question that it reflected what most New Zealanders would like to happen. In fact, there was very widespread condemnation and expressions of concern and so on. The thing we thought was most constructive was to try to gather together a collection of people across different faiths, ethnicities, holding different types of office, prominent New Zealanders, community leaders and get them to sign up to a common statement that could be taken to government. We started doing that by email and phone etc. We got an 
absolutely astonishing response. This issue clearly resonated with a lot of people who ordinarily don't have much to do with each other. I think there was a strong reaction of support from Maori and Pacific people and there was strong support from other ethnic groups and Muslims. And so what actually came out of that was a statement signed by an extraordinary group of New Zealanders including mayors and civic leaders and religious communities. It was very encouraging to see that and it jelled with my discussions in Parliament with the proposal to have a resolution in Parliament. So the two things came together after a few days in terms of the resolution being put into Parliament with the consent of all the parties, and the tabling of this statement by several hundred community leaders. It had the effect of bringing people together in solidarity and concern.

Although this solidarity and concern was highly appreciated, the Diversity Forum at Parliament (also organized by James and Helen McNeish) was originally scheduled for the Jewish Sabbath. It seems that Saturday was most convenient for Sir Paul Reeves, a former Governor-General, whose presence would have added greatly to the occasion. Tony Haas, a secular Jew with intimate knowledge of New Zealand politics, stressed that holding the forum on Saturday would offend Jewish sensibilities. In the end, Sir Paul 'made it clear he would fit in' but it is nevertheless ironic that setting up the healing itself caused some hurt:

There were these different views of how it should be handled. The emotion of the community ran high. This made it hard to operate a hard process. I was . . . caught in the middle of Jewish sentiment that felt the messenger should be shot because I brought them a message about Shabbat that they felt was in conflict with their theological values which I respect but do not feel part of.

Even Parliament's unanimous motion opposing anti-Semitism, a very significant development, had a puzzling twist. David Zwartz got a call from MP Chris Carter the day after the Makara desecration. The Minister asked what the government could do in response. Zwartz suggested:

Why doesn't the NZ Parliament emulate the Australian Parliament with an expression of opposition to anti-Semitism? I think the Makara cemetery thing was on a Thursday and he asked me to see him on a Friday. The Cabinet met on Monday and agreed and on Tuesday when Parliament met they passed a resolution unanimously. And then a very strange thing [occurred]. Jonathan Hunt, the Speaker, said he would send the resolution to the Speaker of the Knesset which in a way was quite inappropriate because what had happened at the cemeteries here had 
nothing to do with Israel except that I had made the link between the Bolton Street [incident] following on from the Prime Minister's remarks about the Israeli passports and I don't know whether the speaker was cocking a snook at Helen Clark. Logically, if the resolution was going to be sent anywhere, it would be sent to the New Zealand Jewish Council as representatives of the Jewish community.

An additional issue discussed with the Race Relations Conciliator was the tendency to confuse Jews and Israel and how problematical this can be for the local community. In interview, it was mentioned that this action, however welcome, seemed an instance of this confusion:

Yes absolutely. It wasn't at my request. That was a spontaneous statement by the Speaker of the House. The actual resolution and statement was not directed in any way at the government of Israel or the Parliament of Israel. It was Jonathan Hunt who said he would do that . . . I'm aware of that sort of feeling. Personally, I make that distinction very clearly and always have. In fact, one of the things traditionally in New Zealand is that people leave their baggage behind as it were. I said at the synagogue, 'Bring your luggage but leave your baggage behind'. I think that's why people across divides like Catholics and Protestants in Ireland, Jews and Palestinians, Serbs and Croats or whatever, we manage to overcome or build bridges between those groups in New Zealand.

The statement the Race Relations Conciliator made about luggage and baggage in our interview fits very nicely with Berry's idea ${ }^{6}$ that the healthiest accommodation strategy a minority group can make is integration: to remain committed to its institutions and cultural practices while participating fully in the wider society. Our impression, from research and participation in the Jewish community, is that this is what local Jews do on a personal and communal level, even though a tendency to privatize their institutions and culture blunts the potential of this strategy to deliver positive results for them. Be that as it may, the government's liberal policies on minorities, so ably pursued by the Minister of Ethnic Affairs, the Race Relations Office and Parliament, were overshadowed, for some informants, by the strong condemnation of the spies by the Prime Minister.

\section{Perceptions of the Links Between the Prime Minister's Reaction to the Spies and the Desecrations}

David Zwartz said,

I don't know if what Helen Clark did was a calculated insult, but it was very strongly harmful to the Jewish community in the way she made her statement and my impression was, and still is, that is what triggered 
whoever did it to think, 'Well, that's alright, we'll go along with what Helen Clark said and bash up the graves.'

Other informants said that their objection was not to the Prime Minister's condemnation of the spies but to the forcefulness of her denunciations and the cutting of ties with Israel. This 'did not help anybody' make the distinction between the actions of the Israeli government and local Jews. The image one gets from these individuals is that there are always anti-Semites lurking in the background and it does not take much to stir them up:

Somebody says Israel is bad, people go and take it out on the nearest representatives of Israel they can find - Jews. Right there. The National Front, a Nationalist psycho patriotic group of people. And so when Helen Clark says that this particular country is bad and they're doing bad things to our country, these people are going to feel personally offended by it and so they'll go and do what they can to take some of their anger out on people.

I can imagine them saying, 'It's a good excuse'. Helen Clarke is bashing Israel, that means Jews are not popular at the moment. We will go and show how outraged we are. It's this bad faith sneaky reasoning and cowardice and Helen Clarke should have foreseen that possibility.

A few of our younger informants were skeptical about there being any such connection. One, who closely monitors right-wing groups and claims to have intimate knowledge of how they work said:

Nazis hate Helen Clark with more of a passion than just about anyone else. They don't care whatsoever for anything she says. They wouldn't have used it as justification. They automatically discount anything she says because she is a socialist and she is trying to introduce gay marriage into New Zealand and she's letting all these immigrants in etc etc. In their minds, she stands for everything they are opposed to. They place no credence whatsoever on anything she says. This isn't speculation. This is going on discussions they've had between themselves that I've read. Helen Clark's reaction was completely irrelevant to their decisions. It was based on the fact that they felt personally attacked by the Mossad spies ...

Another young man said that the PM could hardly have reacted any differently:

The fact was you can't have it both ways. She is the Prime Minister of New Zealand, there was a diplomatic offense against New Zealand. She said what she had to say. It was very appropriate. It wasn't targeted at the Jewish people. It was targeted at Israel as a sovereign nation-state. 
I think if she actually said ... 'Now I want you to know I am slapping diplomatic sanctions onto Israel, but I want you to know it's nothing to do with the Jewish community here', I can imagine the Jewish community going, 'Wow, why did that even come into your mind in the first place? Why did you bring it out in the public arena?' That just shows that there are all kinds of misconceptions and stereotypes happening right there. Like we all support it [Israel].

It is interesting to note that Israeli parliamentarians appeared divided along similar lines. Hemi Doron, from the right-wing Shinui party, claimed that two months before the Israeli passports incident, a Russian intelligence agent was caught in New Zealand. 'The Russian Government apologized. This man was deported from New Zealand and that story was over. They did not intend to hurt us and treat us differently than they did with that Russian agent. All we have to do is learn some humility and admit a mistake.' Other MPs implored Foreign Minister Shalom to own up and apologize for Israel's actions. Several took issue with the claim that the Clark government's response had sparked the graveyard desecration or that there was anti-Semitism in New Zealand. Not one MP directly linked the two events. 7

One informant, who has lived in Israel and works to improve relations between Israel and New Zealand, feels that neither handled the passport affair well. New Zealand could have dealt with things more quietly but Israel hardly helped.

\section{Effects of the Desecrations: The Jewish Community}

The Israelis closed their embassy in Wellington to save money, leaving an Honorary Counsul, who was also head of the Jewish Council, in an uncomfortable dual role precisely when it was imperative for the distinction between Israel and local Jewry to be pointed out:

And it just seems like a conflict of interest for the Israeli Consul to be making that statement on behalf of all New Zealand Jews. And with regards to the conflict of interests he had between being head of the New Zealand Jewish Council and Honorary Consul General for Israel, I felt that conflict of interest has never been more in my face or the face of the collective public than it was in his response to the cemetery desecrations because he was not able to be objective.

Mr Zwartz did indeed relinquish presidency of the New Zealand Jewish Council because of this situation. His dual role shows how responsibilities like this fall on the shoulders of a few select individuals:

[There is a] shortage of people in the Jewish community who are willing to be public about things. And that in itself is a product of the history of 
the Jewish community which has always been low key and subdued with prominent people who never said they were Jewish even if it was known. It wasn't made much of. They themselves didn't make much of it. When it comes to more general communal representation, assumptions made by radio and television crews can have major repercussions. When the media nominated their own 'representative' of the Wellington Jewish Community', this really upset local Jews:

... they decided they wanted to interview me 'cause I was Jewish. And then they go and put me on TV as the Jewish community spokesperson! Yeah, I know at least one person complained about it to someone I know, I don't know where they got that from just 'cause I happen to be Jewish. I thought it was quite inappropriate for them to just kind of stick that title on without asking me.

The desecrations sparked some internal communal friction about whether or not it is appropriate to emphasize a separation between local Jewry and Israel: 'You've got two camps: the people that see a direct link and the people that would rather separate issues to do with Israel from issues to do with the New Zealand Jewish community ... that makes it difficult for the community to choose how to respond'.

On the other hand, the desecrations did lead to increased in-group solidarity and co-operation. Interviewees were impressed at how the Reform and Orthodox communities worked side by side: 'I thought the Jewish community's reaction was stunning. We came together as the kind of community we should be. As a family. And we stood together and worked out an approach and it was wonderful to see both congregations working very well together.'

Others grappled with the question of why it took an anti-Semitic event to unite local Jewry. Some expressed the view that this unification was shortlived: 'I think it did help unify, but I think that effect was quite temporary. I think for probably two months, give or take, there was a bit more sense of community unity that I definitely felt, but after that it was back to same old same old. Which isn't an especially divided community but it's not an especially close-knit community either, it's somewhere in the middle.'

However, the desecrations did have some long-lasting effects. They provided the impetus for more Jewish community outreach work, promulticulturalism activity, anti-racist activity, a new Jewish youth forum and also the formation of INZICC (Israel-New Zealand Information and Cultural Centre). While there was increased public awareness of New Zealand Jewry by default (increased media coverage), local Jews understood there was a greater need for outreach work to educate the general public about Judaism and Jews: 
I think it's made a lot of non-Jewish New Zealanders who may have never even realized that there was a Jewish community in New Zealand realize that there is one, and probably made a few of them want to learn a lot more about it. Which I think is a positive aspect again. But the reality is we are still a tiny, tiny, tiny minority community and most New Zealanders will go through their lives never knowing that they've known a Jew. They may or may not have known a Jew, but they won't know that.

For some of us it was almost empowering. It was like, ok, there's stuff we have to do. We've got to be more open and do some teaching. Raul Ketko organized panel discussions, B'nei B'rit organized interfaith discussions. Dave Moscowitz did outreach with the Muslims. It's more opening ourselves out. And I would sit in that camp. Let's make ourselves more visible and you're going to see with a group that's working on a Holocaust Research Centre. They've got an impetus from the desecrations. That's going to be an enormous project and highly visible and fabulous.

One young member of the Wellington Jewish community described how the cemetery desecrations led to the destruction of the National Front:

I've helped found a website and campaign called Fight Them Back which is a trans-Tasman anti-fascist campaign . . . the National Front's self-destruction this year is almost single-handedly the work of those involved with Fight Them Back, mainly in Wellington.

How did it destroy the National Front?

Constant bad publicity in the press. Every week there'd be an article that we would have got in various newspapers, on TV, in the papers in a bad light, constant pressure on them whenever they would try and do recruitment drives, work with communities to ensure that they didn't happen or if they did happen that they weren't effective and they got hardly any members. A few of them got arrested for various things that we discovered that they had done and they were duly charged, and most of them have been arrested and charged regardless of whether or not they've been convicted and regardless of whether or not they've gone to jail [which has] lessened their involvement because they're scared now. They've realized for themselves, 'What have I gotten myself into?'

The desecrations also provided the impetus for the formation of a new social and educational forum for young Jewish adults, called JewNet. One of the founders described how important it is to cultivate new leadership among young adult Jews: 
. . . on so many of these issues it exhausted David Zwartz or very established people in the community to be the public face of the Jewish community when these things happen, and there's that sustainability issue: if we don't have young leaders in the community, eventually the people who are doing it for us now won't be there [. . .] part of what we wanted to do was to be able to educate and train ourselves into becoming people that would be able to do things for the Jewish community and present a visible public face [. . .] it was a way of actually doing something proactive rather than just feeling like victims.

\section{Effects of the Desecrations: Individual Responses}

We have focused on how the stressful events of the Israeli spy scandal and cemetery desecrations caused the community to re-evaluate its acculturation strategies. Individuals, of course, also faced uncertainty. They were upset and unsure of how to respond. The most obvious initial shock to Wellington Jews was the experience of concrete, physical anti-Semitism as opposed to mild anti-Semitic comments or just plain old ignorance of Jewish concerns. The desecrations were described as 'astonishing and disturbing': 'I never expected it to happen in New Zealand. Because I heard about it happening in France and other places in the world many times before, but to happen in New Zealand . . . was just a shock.'

An important distinction arose between comprehending the nature and scale of the attacks, and seeing them with one's own eyes, which was a chilling experience: 'There were pieces of gravestone everywhere and swastikas carved into the ground. I just got angrier and angrier and couldn't really believe it and couldn't understand until I had seen it that couple of days later.'

While anger towards the perpetrators was an emotion mentioned, this was also accompanied by fear of further communal or interpersonal attacks: 'I think cemetery desecration reaches something to the core of our being, something that you want to have peace for your loved ones and yourself once you've gone and that is stepping completely over the line'. 'I guess some little penny started to drop and you know how people talk about canaries down mines and when the canary dies the miners need to get out and I was like "Is this a sign of things to come?", people were saying and I didn't think it was a sign of things to come but I knew people would be starting to feel really scared.'

Affective reactions differed according to the level of personal involvement. Members of the Wellington Hebrew Congregation were more deeply affected if their family graves were desecrated: 
It was surprising. It was like they just died. It was the same grief that they'd just passed away since they were so unsettled. For Jewish people who don't cremate, you have a physical presence and you mark that. That physical presence becomes part of your life in terms of you go to the grave on anniversaries of the death and you acknowledge the physical remains. And mentally and emotionally that's where they are in your mind and you suddenly hear that they are disturbed. I felt like at night I didn't want to sleep. I wanted to be at the cemetery beside them. And it wasn't until the graves had been returned to their former state that I felt I could settle again. I felt their spirits were very unsettled and disturbed. It was the same pain as the deaths. It was very emotional. It was very painful. It was pain that we'd done nothing to generate or cause. It was completely heedless pain. Unlooked for pain and unexpected.

The programmed nature of both desecrations, the physical damage, the presence of swaztikas and the burning of the prayer house in Makara led to comments about the level of seriousness of the attacks:

... this was a unique event in NZ recent history. It was basically the first anti-Semitic thing that had ever happened in living memory of any significance. There had been vandalism before but this is the first time there was significant property damage. It had such seemingly hateful actions behind it.

Because a lot of the reasons why my parents left home (and their friends left Russia), was because of anti-Semitism [. . .] and for them to have it come here in such an immediate and apparent way as the desecration of graves was disgusting

Going on to an unlit cemetery in the dark, you'd have to be pretty determined. It's a significant disincentive to enter that place if you don't have a car. It's interesting with the gate being unlocked. Has that ever been accounted for? Someone didn't do their job. The person might not be responsible but there should be some follow up about that.

Further complaints from interviewees concerned the lack of communication regarding the Police investigation. Respondents asked during interviews if there were any convictions, and others were left with an impression of the case disappearing into thin air.

In regard to behavioural responses, a very altruistic reaction was to look out for others, whether youth, peers or elderly, 'especially people that didn't have family in Wellington that might not be feeling good about the situation and I thought people really need a space to vent how they are feeling and if people are feeling threatened, then what better environment for people to gain strength [than] from other young Jewish people? So that was my only real response, was to make sure people my age in the community felt ok.' 


\section{Effects of the Desecrations: Public Responses}

While some Jews took the more proactive responses outside the Jewish community mentioned previously, all those interviewed expressed the desire that the community remain calm. However, opinions differed in regard to what actions were deemed appropriate. Care was taken in organizing the ceremonies at Bolton Street and Makara. The priority for Bolton Street was to show the wider New Zealand community that events such as this do matter to all of us. Yet it was to be 'low-key', an expression that highlights the tension between raising public awareness while not wanting to focus undue attention on the Jewish community. The rededication at Makara was more of a private religious affair, likened to a funeral. Community opinion was, however, polarized regarding the private vs. public nature of the Makara rededication. While interviewees sympathized with those who wanted to grieve in a close communal setting, some felt that in having the Jewish-only event, a lot of public sympathy was lost.

Perceptions of responses from the New Zealand public also varied. Generally, interviewees described receiving a lot of empathy from those around them, which they found very heartening:

From the moment they heard about it, especially after Makara, once they found out that my family had been involved but even beforehand, even at Bolton Street, really there was support. And they didn't really know what to do. I mean I didn't know what to do either but they were there to support me should I want them, and should I not, they were fine with that, if I just wanted to go through it on my own. But they were really supportive from the instant they found out about it. It was a really, really positive response and it made me realize they were good friends 'cause they were there during the hard times as well as the good.

Empathy was also apparent in the media, with article headings like: 'Shame: Vandals wreak havoc in Jewish cemetery' (Dominion Post, 7 August 2004), and statements such as that from the Mayor who called on all Wellingtonians to support the Jewish community: 'This is an appalling act of vandalism . . . and I am disgusted and ashamed that it has happened in our city'. Ethnic Affairs Minister Chris Carter also used the media to seek public messages of 'support and friendship for the Jewish community'. The media went so far as to print an article that extolled the virtues of local Jewry: 'Wellington's Jewish community has long played an active part in the city's cultural and business life out of proportion to the group's small size. Once a community noted in the clothing and furniture trade, many of Wellington's Jews are prominent in business, the professions, the arts and philanthropy'. 
However, interviewees also noted that some non-Jews lacked understanding of the events and what they meant:

I was surprised people weren't coming up to me and saying, 'Wow, this is ludicrous'. That really took me aback, and I never approached anyone about it but I can't recall anyone coming up to me, with the exception of one person actually and saying, 'How are you feeling, what is the mood within the community at this time?'[. . .] I expected more, to be honest. The silence was deafening.

I think New Zealanders don't understand the significance of it. It's just like, 'Oh yeah, it's bad to vandalize cemeteries', but they don't understand that because it's a Jewish cemetery it's not the same as if it was the cemetery where their own grandparents were buried. They don't understand that the race factor is relevant.

Even when you are talking about a cemetery desecration, it's not just - when you see a swastika in the ground for another person it may just be a really bad symbol of the Nazi regime but it doesn't bring up that sentiment of family history or your heritage.

For these interviewees, the differences of the reactions to these events amongst Jews and non-Jews, and the limitations to the possibility of shared meanings highlight the distinctiveness of being Jewish in New Zealand:

... it's almost living these two separate worlds. There's the Jewish world where people understand things and you share common experiences and when something like this happens that's where you talk about it. And there's your non-Jewish world, where you maybe don't necessarily even bother to try to engage people about these issues because they don't understand or they say something that upsets you, or they don't think it's that important, or maybe they do think it's important but they don't see it the same way.

\section{Conclusion}

The vandalism of the two Jewish cemeteries in Wellington in 2004 confronted New Zealand and its Jewish community with both problems and opportunities. The events created a rare instance where local Jewish concerns entered into the nation's public consciousness. Questions of loyalty, discrimination, profile, cultural understanding and mutual accommodation were all raised in the context of events involving a small, normally invisible ethnic community. The desecrations showed Jews that their comfortable situation in New Zealand is more precarious than they thought. The community's low-key public stance, close identification with Israel and narrow leadership base left it vulnerable to attack by a small 
group of extremists. Although it is doubtful that the community will change fundamentally as a result of the desecrations, reactions to them did demonstrate that the community does contain resourceful people capable of rising to meet challenges to the Jewish continuity in New Zealand. Despite the fact that the current government's attitude towards Israel continues to concern local Jews, the mutual commitment to multiculturalism, so obvious in reactions to these events, firmly anchors their community to mainstream Kiwi society.

1 A. Beaglehole and H. Levine, Far From the Promised Land?: Being Jewish in New Zealand, Wellington: Pacific Press, 1996, pp.139-41.

2 B. Lewkowicz, 'Greece Is My Home, But . . . Ethnic Identity of Greek Jews in Thessaloniki', Journal of Mediterranean Studies, 4, 2 (1994), pp.225-40.

3 F. Lingel, 'Israeli Agents Arrested in Plot to Forge Passports Mossad Targeted Handicapped; Kiwi PM Breaks Diplomatic Ties', American Free Press, 2004.

4 Ibid.

5 J. Woocher, Sacred Survival the Civil Religion of American Jews, Bloomington: Indiana University Press, 1986; H.B. Levine, 'The Secular Ideology of Jewish Ethnicity in New Zealand ', Contemporary Jewry, 14 (1993), pp.94-115.

6 J.W. Berry, 'Psychology of Acculturation: Understanding Individuals Moving Between Cultures', in R. Brislin (ed.), Applied Cross-Cultural Psychology, Newbury Park, pp.232-53.

7 Lingel, 'Israeli Agents'.

8 D. McLoughlin, 'Jews Play Vital Role in City', Dominion Post (Wellington), 9 August 2004. 